\title{
Testing knowledge sharing effectiveness: trust, motivation, leadership style, workplace spirituality and social network embedded model
}

\author{
Muhammad Sabbir RAHMAN \\ International Islamic University, Malaysia \\ AAhad M. OSMAN-GANI \\ International Islamic University, Malaysia \\ Md. Abdul MOMEN \\ East-West University, Bangladesh
}

Nazrul ISLAM

East-West University, Bangladesh

\begin{abstract}
The aim of this inquiry is to investigate the relationships among the antecedents of knowledge sharing effectiveness under the position of non-academic staff of higher learning institutions through an empirical test of a conceptual model consisting of trust, extrinsic and intrinsic motivation, leadership style, workplace spirituality and online social network. This study used the respondents from the non-academic staff of higher learning institutions in Malaysia $(n=200)$, utilizing a self-administered survey questionnaire. The structural equation modeling approach was used to test the proposed hypotheses. The outcomes indicate that all the antecedents play a substantial function in knowledge sharing effectiveness. In addition, perceived risk plays a mediating role between trust and knowledge sharing effectiveness. On the other hand, this research also proved the communication skill also plays a mediating role between leadership style and knowledge sharing effectiveness. This study contributes to pioneering empirical findings on knowledge sharing literature under the scope of the nonacademic staff perspective.
\end{abstract}

Keywords: Knowledge sharing effectiveness, higher learning institutions, trust, motivation, leadership style, workplace spirituality and social network

Please cite the article as follows: Rahman, M.S., Osman-Gani, A.M., Momen, M.A. and Islam, N. (2015), "Testing knowledge sharing effectiveness: trust, motivation, leadership style, workplace spirituality and social network embedded model", Management \& Marketing. Challenges for the Knowledge Society, Vol. 10, No. 4, pp. 284-303, DOI: 10.1515/mmcks-20150019.

\section{Introduction}

The refinement of the knowledge sharing environment is distinguished as one of the most vital resources for the growth of world class higher learning institution,

Correspondence: Muhammad Sabbir Rahman sabbiriiu@ gmail.com 
especially when the higher education sector in a country like Malaysia is continuously spreading out. The Ministry of Higher Education (MOHE) reports that more than 900,000 students pursuing higher education in 20 public universities, 33 private universities and university colleges, 4 foreign university branch campuses, 22 engineering schools, 37 community colleges and nearly 500 private colleges. In this context, knowledge sharing among the non-academic, administrative staff has been pertinent since these non-academic staff play an important role in serving their internal and external customers. Therefore, this research will produce a conceptual model that mixes all the related antecedents of knowledge sharing effectiveness by focusing on their (non-academic staff) perceive behavioral and attitudinal pattern of knowledge sharing practices.

This combination of the derivation of this type of conceptual framework is required by the authorities of higher learning institutions in order to explore in details about the nature of knowledge sharing among the non-academic staff from higher learning institution perspective. Sharing of knowledge among the administrative staff is vital in confronting the new challenges to fulfill their respective client's needs. Such an understanding will help the managers and the policy makers of a higher learning institution to foster its organizational success and their sustainability in the longer term (Fong et al, 2011). Results from previous empirical study revealed that there is a significant relationship between the attitudes of knowledge sharing and their intention to share knowledge (Bock and Kim, 2002; Yaghi et al., 2011). For instance: the findings by Ellahi and Mushtaq (2011) asserted that the attitudes of bloggers, towards knowledge sharing, significantly affected their intention to share knowledge in blogs. In addition, learning organization is the result of the whole process of an organization where employees intention or willingness to share their knowledge to optimize the organizational learning process which may convert the tacit knowledge into explicit knowledge. As a result, everybody in the organization needs to share the information (Howard, 2002).

Yet, research on testing the influence of all cultural elements in the establishment of the antecedents of knowledge sharing effectiveness is beyond the range of this study due to time, resource and scope constraints. Previous empirical findings report that workplace spirituality, leadership skill, motivation and trust among the staff, enhance the knowledge sharing effectiveness in an organization (Bratianu and Orzea, 2011; Lilleoere and Hansen, 2011; Politis, 2003; Gruenfeld et al., 1996; Smith and Rupp, 2002; Connelly and Kelloway, 2003; Syed-Ikhsan and Rowland, 2004; Goh, 2002; Long and Mills, 2010; Mitchell and Boyle, 2009; Tse and Mitchell, 2010). Evidence from past empirical research also explains that the influence of social networks has also played an important role in knowledge sharing effectiveness among the staff in an organization (Bose and Scheepers, 2007; Cross et al., 2002; Tsai, 2001). Thus, this research will thus propose a model by empirically examining the degree of relationship of trust, motivation (intrinsic and extrinsic), leadership style, workplace spirituality and social network towards knowledge sharing effectiveness among nonacademic administrative staff of higher learning institutions. The result of this inquiry may add value in offering guidelines for the higher learning institutions as well as the policy makers to understand the antecedents of knowledge sharing effectiveness under the position of non-academic staff of higher learning establishments in 
MMCKS

Malaysia, which were not previously searched. The propose research may definitely contribute for both academics and practitioners in various aspects. From a theoretical view, this research will provide a comprehensive understanding of the direct impact of workplace spirituality, leadership skill, motivation, trust, social network on knowledge sharing effectiveness. This research also tested the mediation role of perceived risk, communication skills in between, trust and leadership style (See figure 1) in higher learning institutions context which were not explored yet. In terms of practical implications, the findings of this research will definitely assist the authorities of higher learning institutions to initiate and maintain a knowledge sharing environment in their respective department by focusing on the significant factors explore from this research. The random sampling method was adopted where non-academic, administrative staff of the selected public and private higher learning institutions in Malaysia was taken as the unit of analysis. The data were analyzed by using descriptive statistics followed by exploratory factor analysis (EFA), confirmatory factor analysis (CFA). In addition, structural equation modeling (SEM) was employed to examine the full structural model. This research will respond to the following research question:

How the antecedents of various cultural elements do relate to knowledge sharing effectiveness among non-academic, administrative staff of higher learning institutions in Malaysia?

\section{Conceptual framework development}

Knowledge sharing is an operation of exchanging knowledge with others (Davenport and Prusak, 1998). This affirms that knowledge sharing is a collective function of the members of an organization (Van den Hooff and De Ridder, 2004) where the members are practicing a standard set of values and rules that are apportioned by the group member in an organization. Therefore, knowledge sharing effectiveness provides a system of rules that gives a direction for an action to accomplish the organization's pre-specified objectives (Hofstede, 1991; Kotter and Heskett, 1992; Meek, 1988; Rousseau, 1995). Thus, the significance of cultural elements is ensuring the knowledge sharing effectiveness, which has widely researched under various research scopes (De Long, 1997; Gold et al., 2001). The bulk of research in this area suggests organizational cultural elements are the possible basis for success or barriers for the processes of knowledge sharing environment in an organizational climate (De Long and Fahey, 2000; McDermott and O'Dell, 2001; Smith, 2003; Davenport et al., 1998; Janz and Prasarnphanich, 2003). The next section will explain the role of those significant elements that relates to knowledge sharing effectiveness among the members of an organization with respect to develop the conceptual framework of this research (See Figure 1).

\section{Trust, perceived risk and knowledge sharing effectiveness}

Trust can be defined as: 
"The extent to which one is willing to ascribe good intentions and have confidence in the words and actions of other people"

McEvily et al. (2003) explore that trust variable plays an important role towards knowledge sharing effectiveness in an organization. Numerous researchers also agreed that trust is an essential ingredient for building a knowledge base organization with the work groups. Previous research also shows that trust leads to an increase in overall knowledge sharing intensity among the members of an organization (Mayer et al., 1995; Szulanski et al., 2004, Adler, 2002; De Long and Fahey, 2000; Hinds and Pfeffer, 2003; Van den Hooff and Van Weenen, 2004; Lin, 2007 and Hislop, 2003). However, the role of perceived risk by the member of an organization may act as a mediating function in between, trust and knowledge sharing behavior in an organization where this research will further investigate (Newell et al., 2002). Consistent with these above arguments, findings, the following hypothesis are formulated for further empirical examination:

Hypothesis 1(H1): Perceived risk significantly mediates the relationship between trust and knowledge sharing effectiveness among the non-academic administrative staff of higher learning institutions.

\section{Leadership style, communication style and knowledge sharing effectiveness}

Leadership has considered an important element in the success of a knowledge-based institution. There is a significant relationship exists between leadership styles and the success of knowledge sharing environment (Mitchell and Boyle, 2009; Tse and Mitchell, 2010; Pieterse et al., 2010; Shin and Zhou, 2003). Bollinger and Smith (2001) identify the function of leadership style in order to establish a culture that may enhances to create an environment for knowledge sharing. They also explore that the effective leadership style through a proper communication techniques by a leader in an organization will push in the retention of its existing human resources, and building a strong commitment among the member of an institution. Bukowitz and Williams (1999) explain that in a knowledge intensive organization, leaders are no longer play a role of the source of knowledge rather they always adapt with valuecreating knowledge sharing environment for attaining the organizational purposes. That is why leadership capabilities in communication skill can play as an enabler role in an organization of a successful knowledge sharing management (Suri Babu et al., 2007a, b, c, d, e; Nonaka and Konno, 1998).

Thus leader's communication skill is one of the important factors which may significantly influence the strength of the relationship between leadership style and knowledge sharing effectiveness in an institution. According to Axley (1996) communication is not only the combination of oral presentation and writing ability rather it is more extended to a person listening skill as well. Therefore, research has already disclosed that a majority portion of individual listens less effectively than they suppose. So listening is an essential and valuable skill for the managers that may 
MMCKS enhance their communication skill (Cohen, 1988). Based on the above discussion following hypothesis is developed for further empirical investigation:

Hypothesis 2 (H2): There is a significant relationship between leadership style and knowledge sharing effectiveness among the non-academic, administrative staff in higher learning institutions when communication skill significantly mediates the relationship.

\section{Motivation and knowledge sharing effectiveness}

Motivation is recognized as one of the important influences antecedents on knowledge sharing effectiveness in an institution. Osterloh and Frey (2000) categorize two types of motivation for instance: intrinsic and extrinsic motivation. Extrinsic motivation defines as individuals to live up to their needs ultimately by getting supplementary resources such as money, advancement opportunities and other nonfinancial resources (Deci, 1976). On the other hand, intrinsic motivation can be defined as an action by an employee who is valued for its own sake and appears to be a self-sustaining for him/her (Deci, 1976). In addition, Lindenberg's (2001) divide intrinsic motivation with normative (i.e., sense of conformity with personal and social norms) and hedonic (i.e., meeting in self-determined, individual capability and enjoyable activities) (Kreps, 1997; Azman et al. 2013). That is why Osterloh and Frey (2000) suggest that intrinsic motivation is more important when sharing tacit knowledge. Grounded in the above discussion following hypotheses are formulated for further testing:

Hypothesis 3(H3): Intrinsic motivation significantly relates knowledge sharing effectiveness among the non-academic, administrative staff in higher learning institutions.

Hypothesis 4 (H4): Extrinsic motivation considerably affects the relationship towards knowledge sharing effectiveness among the non-academic administrative staff in higher learning institutions.

\section{Spirituality in workplace and knowledge sharing effectiveness}

Every human being receives its own emotional quality which is embedded by spiritual intelligence as it represents the mixture of goodness, honesty, attractiveness and sympathy (Zohar and Marshall, 2004). In this aspect, workplace spirituality can be highlighted through two different looks. The first single is the individual's staff experience with his/her inner feelings (Kinjerski and Skrypnek, 2004) and the second one is his/her workplace experience (Jurkiewicz and Giacalone, 2004). Workplace spirituality influences the attitudes of the employees to formalize a learning organization where knowledge sharing plays a significant role (Milliman et al., 2003; Vasconcelos, 2013). Based on the previous discussion the following hypothesis can be developed for further empirical test:

Hypothesis 4(H4): There is a substantial relationship between spirituality in the workplace and knowledge sharing effectiveness among non-academic administrative staff in Higher learning institutions. 
Social network and knowledge sharing

Social network plays an important tool that visualizes knowledge and the relationships between people within the departments (Cross et al., 2002). Helms and Buijsrogge (2006) remark that using social networking in an organization is rooted through the shared knowledge from the experts to the non-experts through lively participation. According to Wellman et al. (1996) computer-mediated communication media such as Facebook, Hyves, and LinkedIn may help every individual in an organization an unprecedented power to connect with each member where various online social networks play a significant role. Research by McCarthy et al. (2008) observes that online sharing of information generates strong relationship in the workplace. This relationship improvement had an indirect benefit to professional relationships among the staff of an organization (Viadesk, 2011). This leads to test the following hypothesis:

Hypothesis 5(H5): There is a significant connection between social networks and knowledge sharing effectiveness among non-academic, administrative staff in institutions of higher learning.

Having looked through all of these previous resources; this study would like to propose the following model for further empirical investigation:

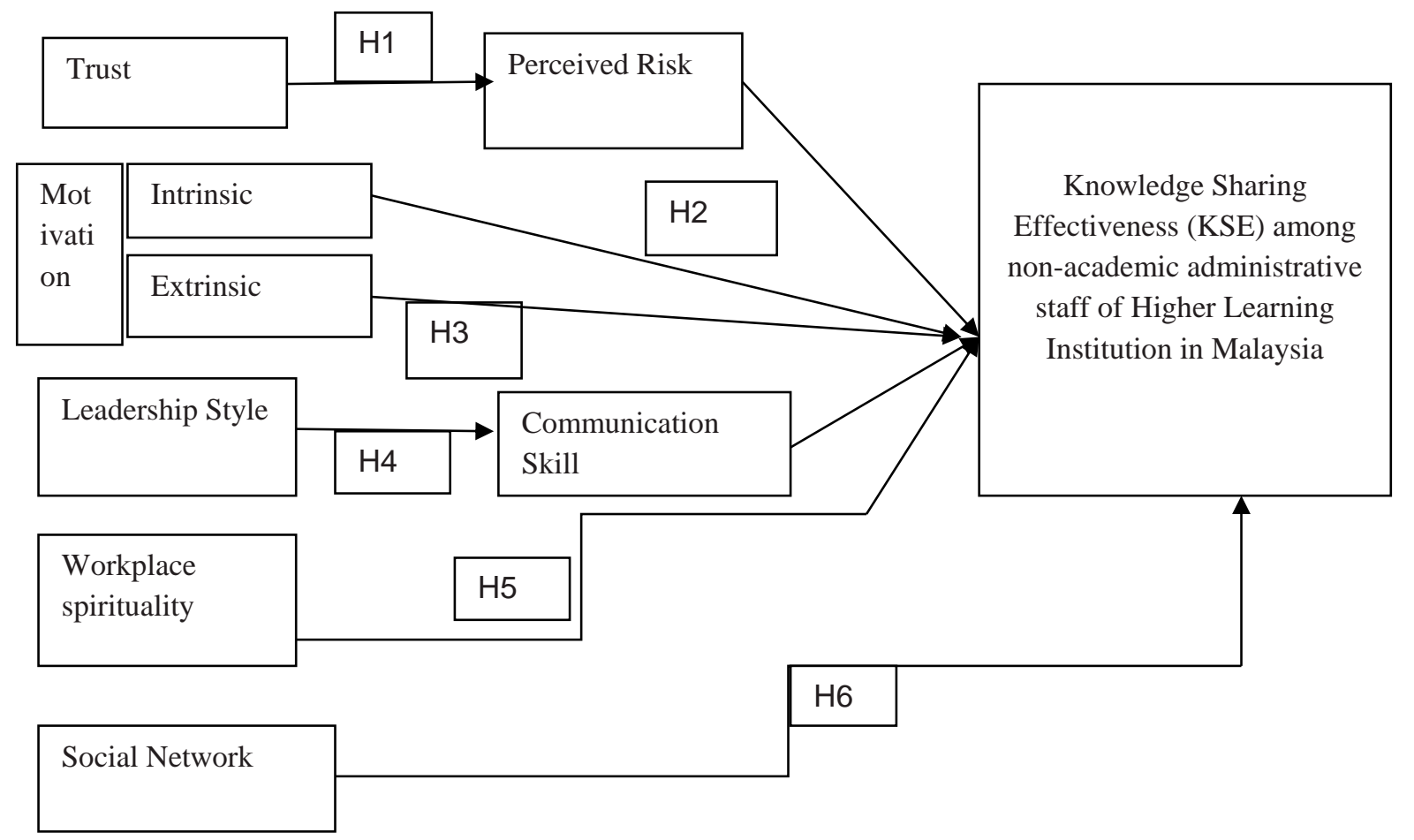

Figure 1. Conceptual framework of measuring knowledge sharing effectiveness among the nonacademic administrative staff of higher learning institutions

Source: Authors' own model. 


\section{MMCKS Research methodology}

This study covers the non-academic staff from different higher learning institutions in Malaysia. This research covered a standard amount of respondents (200) through a cross sectional approach from different public and private universities in the Klang Valley area in Malaysia. Our propose sample frames included the non-academic, administrative employees who are playing in various administrative posts at different public and private universities in Malaysia.

A sum of 200 respondent's responses was accumulated for final data analysis. This research used a multivariate data analysis methods to bring up the raw information into a pattern that made it easy for the researcher and reader to infer the direction of the research output. In this study, seven point-Likert scale was used in questionnaires. The respondents who completed the questionnaires in this research were allowed to put their answer anywhere on the scale (1= Very strongly disagree; 7= Very Strongly Agree). More importantly seven points Likert scale with all points labelled were used for the collection of the data as this type of scale is widely applied by management researchers which actually allows for a stage of intensity and feelings to be conveyed.

In order to operationalization of the constructs, this research adapted scales from Kuo (2013) research for measuring trust and perceived risk (Trust-Tr-3 items; Perceived Risk-Pr), Akhavan et al., (2013) research for measuring intrinsic and extrinsic motivation (Intrinsic Motivation-Int- 4items, Extrinsic Motivation- Extrn- 4 items), Hoch (2014) for measuring the leadership style (lead-4 items), Snyder and Lee-Partridge (2013) research for measuring communication skill (Cs-4items), Zabriskie (2005) research for measuring spirituality(Ws-4items), Panahi et al. (2012) study for measuring online social network variable. In the first phase of the data analysis this research will utilize confirmatory factor analysis (CFA) to support the factor structure. Hence, in this study structural equation modeling were employed to test the hypothesis. In evaluating the "goodness of fit" this research used fit indices included in the comparative fit index (CFI); the goodness -of-fit index (GFI); the normed fit index (NFI); Tucker Lewis Index (TLI) and the root mean square error approximation (RMSEA).

\section{Data analysis}

Reliability and Validity tests

This research used reliability and validity to examine the constructs (see Table 1) with multivariate data analysis measures. To evaluate the inner consistency of the data Cronbach's $\alpha$ was applied to of these study scales (Nunnally, 1978). The result of Cronbach's $\alpha$ of each constructs produce a satisfactory outcome with values, not below 0.75 indicates a satisfactory internal consistency of the data under each construct (Cuieford, 1965). The results from confirmatory factor analysis reflect that all the item loadings under each construct are significant (See Table 1). The convergent validity of the scales was achieved through by examining the results of average variance extracted (AVE). All the constructs respective AVE is greater than 0.5 shows the scales have sufficient convergent validity. The construct validity was tested by testing the pooled measurement model (See Table 3 and Figure 2). All the 
respective goodness of fit achieves the threshold suggested by Hair et al. (1995). To achieve the discriminant validity, researchers analyzed the average variance extracted which must exceed the square of the constructs respective correlations (See Table 2). Therefore, all the constructs in this research reflect both convergent and discriminant validity.

Table 1. Cronbach alpha and Comparative Fit Index (CFI) for individual constructs

\begin{tabular}{|c|c|c|c|c|c|}
\hline Constructs Name & $\begin{array}{c}\text { Loadings } \\
\left(\mathbf{R}^{2}\right)\end{array}$ & $\begin{array}{c}\text { Construct } \\
\text { Reliability } \\
\text { (Above } \\
0.7)\end{array}$ & $\begin{array}{c}\text { Variance } \\
\text { Extracted } \\
\text { (AVE) } \\
\text { (Above } \\
0.6)\end{array}$ & $\begin{array}{r}\text { Cronbach } \\
\text { Alpha } \\
\text { Coefficient }\end{array}$ & CFI \\
\hline $\begin{array}{c}\text { Trust }(\operatorname{Tr}) \\
\operatorname{Tr} 2 \\
\operatorname{Tr} 3 \\
\operatorname{Tr} 4 \\
\text { Overall average mean }=4 . \\
22\end{array}$ & $\begin{array}{l}.62 \\
.89 \\
.82\end{array}$ & .82 & .61 & 0.80 & 0.89 \\
\hline $\begin{array}{c}\text { Intrinsic Motivation } \\
\text { (Intrinsic) } \\
\text { Int1 } \\
\text { Int2 } \\
\text { Int3 } \\
\text { Int4 } \\
\text { Overall average } \\
\text { mean }=4.188 \\
\end{array}$ & $\begin{array}{l}.65 \\
.83 \\
.84 \\
.79\end{array}$ & .79 & .61 & 0.79 & 0.86 \\
\hline $\begin{array}{c}\text { Extrinsic Motivation } \\
(\text { Extrn) } \\
\text { Extrn } 1 \\
\text { Extrn2 } \\
\text { Extrn3 } \\
\text { Extrn4 } \\
\text { Overall average mean=4. } \\
\text { 288 }\end{array}$ & $\begin{array}{l}.84 \\
.81 \\
.90 \\
.87\end{array}$ & .88 & .73 & 0.82 & 0.89 \\
\hline $\begin{array}{c}\text { Leadership Style (Lead) } \\
\text { Lead1 } \\
\text { Lead2 } \\
\text { Lead3 } \\
\text { Lead5 } \\
\end{array}$ & $\begin{array}{l}.91 \\
.86 \\
.74 \\
.84 \\
\end{array}$ & .89 & .70 & 0.86 & 0.88 \\
\hline $\begin{array}{c}\text { Work Place Spirituality } \\
\text { (WS) } \\
\text { Ws1 } \\
\text { Ws2 } \\
\text { Ws3 } \\
\text { Ws5 } \\
\text { Overall average } \\
\text { mean=4.605 }\end{array}$ & $\begin{array}{l}.75 \\
.87 \\
.83 \\
.85\end{array}$ & .85 & .68 & 0.85 & 0.87 \\
\hline Social Network (SN) & & & & 0.79 & 0.85 \\
\hline
\end{tabular}

Vol. 10, No. 4, Winter, pp. 284-303, ISSN 1842-0206 | Management \& Marketing. Challenges for the Knowledge Society 
MMCKS

292

\begin{tabular}{|c|l|l|l|l|l|}
\hline Sn1 & .77 & .83 & .69 & & \\
Sn2 & .83 & & & \\
Sn3 & .78 & & & \\
Sn4 & .78 & & & \\
Overall average \\
mean=4.105 & & & & \\
\hline $\begin{array}{c}\text { Communication Skill } \\
\text { Cs1 }\end{array}$ & .78 & .79 & .59 & 0.75 & 0.89 \\
Cs2 & .81 & & & \\
Cs3 & .66 & & & \\
Cs4 & .87 & & & \\
Overall average & & & & \\
mean=4.305 & & .77 & .56 & 0.79 & \\
\hline Perceived Risk & .74 & & & \\
Pr1 & .74 & & & & \\
Pr2 & .86 & & & & \\
Pr3 & .80 & & & & \\
Pr4 & & & & & \\
Overall average & & & & \\
mean=4.505 & & & & & \\
\hline
\end{tabular}

Source: Authors' own processing. 


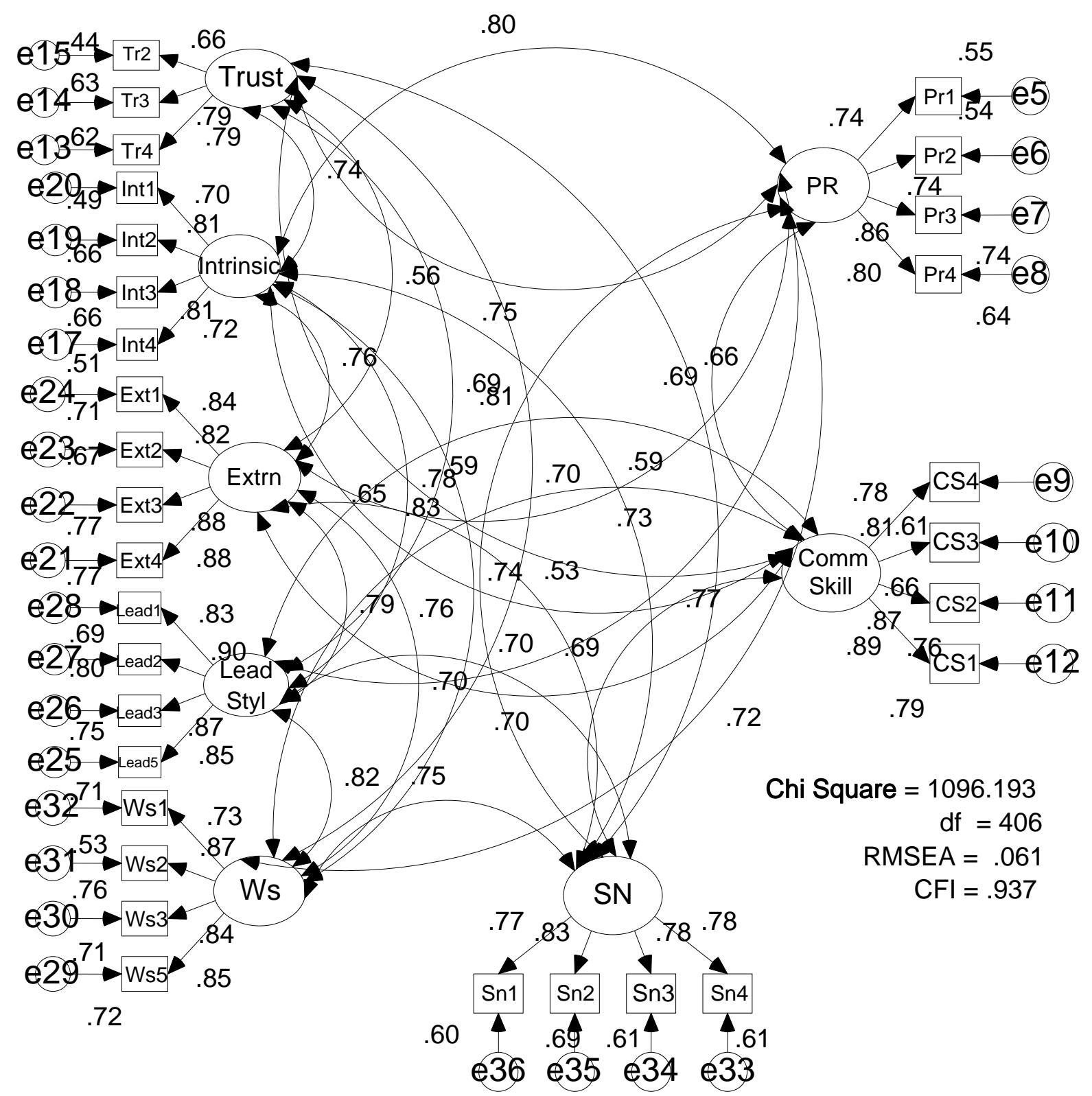

MMCKS

Figure 2. The measurement model combining all constructs simultaneously (Note; Extrn = Extrinsic Motivation, Lead_Styl = Leadership Style, WS = Workplace Spirituality, SN= Social Network, Comm_Skill = Communication Skill)

Source: Authors' own processing.

Table 2. The discriminate Validity Index Summary (For Independent Variables)

\begin{tabular}{|l|r|r|r|r|r|}
\hline Items & Trust & $\begin{array}{l}\text { Intrinsic } \\
\text { motivation }\end{array}$ & $\begin{array}{l}\text { Extrinsic } \\
\text { motivation }\end{array}$ & \multicolumn{1}{l|}{$\begin{array}{l}\text { Leadership } \\
\text { style }\end{array}$} & \multicolumn{1}{|l|}{$\begin{array}{l}\text { Workplace } \\
\text { spirituality }\end{array}$} \\
\hline & & & & & \\
\hline Trust & 0.61 & 0.5476 & 0.5776 & 0.6889 & 0.4624 \\
\hline $\begin{array}{l}\text { Intrinsic } \\
\text { motivation }\end{array}$ & 0.74 & 0.61 & 0.5776 & 0.4624 & 0.6241 \\
\hline Extrinsic & 0.76 & 0.76 & 0.73 & 0.6241 & 0.5476 \\
\hline
\end{tabular}

Vol. 10, No. 4, Winter, pp. 284-303, ISSN 1842-0206 | Management \& Marketing. Challenges for the Knowledge Society 


\begin{tabular}{|l|r|r|r|r|r|}
\hline motivation & & & & & \\
\hline Leadership style & 0.83 & 0.68 & 0.79 & 0.7 & 0.6724 \\
\hline $\begin{array}{l}\text { Workplace } \\
\text { spirituality }\end{array}$ & 0.70 & 0.7 & 0.74 & 0.82 & 0.68 \\
\hline
\end{tabular}

Source: Authors' own processing.

Note: Here, AVE is placed on diagonal value, below the diagonal is the correlation value, top of the diagonal is the multiple correlation value

Table 3. Goodness of fit indices for the measurement model

\begin{tabular}{|l|l|l|}
\hline Goodness of fit indices & Fit Criteria & $\begin{array}{l}\text { Result from the } \\
\text { Measurement Model }\end{array}$ \\
\hline $\mathrm{X}^{2}$ & & 482.757 \\
\hline $\mathrm{df}$ & & 197 \\
\hline $\mathrm{X}^{2} / \mathrm{df}$ & Not more than 3 & 2.69 \\
\hline GFI & Closer to 1 & 0.960 \\
\hline AGFI & Closer to 1 & 0.948 \\
\hline CFI & Closer to 1 & 0.937 \\
\hline RMSEA & $\leq 0.07$ & 0.061 \\
\hline NFI & Closer to 1 & 0.921 \\
\hline
\end{tabular}

Source: Adapted from Hair et al. (1995).

\section{Hypotheses testing}

In the proposed conceptual framework, trust, intrinsic motivation, extrinsic motivation, leadership style, workplace spirituality and social network are considered as exogenous variable, and knowledge sharing effectiveness among the non-academic staff of higher learning institutions is considered an endogenous variable, while perceived risk and communication skills were considered as a mediating variable. The outcomes of the overall fit of the model are highlighted in table 4 . The results of absolute fit measures $(\mathrm{GFI}=0.945, \mathrm{AGFI}=0.937$ and $\mathrm{RMSEA}=0.063$ ) represent that the full structural model meets the recommended levels which fit satisfactory for the sample data. The Chi-square/DF also indicates a well fit at 2.80. Thus the researchers concluded that the proposed model preserves the construct validity. Figure 3 reflects the factor loadings of the items under each construct. All the loadings are significant under each construct (See Figure 2) thus indicate the unidimensionality of the measuring items. The results from the structural equation model highlights that all the relationship are significant except the relationships between leadership style and knowledge sharing effectiveness. Therefore, this research accepts hypotheses H2, H3, H5 and H6.

Table 4. The Standardized Regression, Weight of among the Constructs

\begin{tabular}{|l|l|l|r|r|r|r|l|}
\hline \multicolumn{2}{|c|}{ Relationship Among the Constructs } & Estimate & \multicolumn{1}{c|}{ S.E. } & C.R. & P & Label \\
\hline Perceived Risk & $<---$ & Trust & .655 & .076 & 8.581 & $* * *$ & Sig \\
\hline $\begin{array}{l}\text { Communication } \\
\text { Skill }\end{array}$ & $<---$ & Leadership Style & .704 & .065 & 10.880 & $* * *$ & Sig \\
\hline $\begin{array}{l}\text { Knowledge } \\
\text { Sharing }\end{array}$ & $<---$ & Perceived Risk & .243 & .095 & 2.556 & .016 & Sig \\
\hline
\end{tabular}

Vol. 10, No. 4, Winter, pp. 284-303, ISSN 1842-0206 | Management \& Marketing. Challenges for the Knowledge Society 


\begin{tabular}{|c|c|c|c|c|c|c|c|}
\hline \multicolumn{3}{|c|}{ Relationship Among the Constructs } & \multirow[t]{2}{*}{ Estimate } & \multirow[t]{2}{*}{ S.E. } & \multirow[t]{2}{*}{ C.R. } & \multirow[t]{2}{*}{$\mathbf{P}$} & \multirow[t]{2}{*}{ Label } \\
\hline Effectiveness & & & & & & & \\
\hline $\begin{array}{l}\text { Knowledge } \\
\text { Sharing } \\
\text { Effectiveness }\end{array}$ & $<---$ & Social Network & .239 & .091 & 2.636 & .013 & Sig \\
\hline $\begin{array}{l}\text { Knowledge } \\
\text { Sharing } \\
\text { Effectiveness }\end{array}$ & $<---$ & $\begin{array}{l}\text { Intrinsic } \\
\text { Motivation }\end{array}$ & .588 & .111 & 5.297 & $* * *$ & Sig \\
\hline $\begin{array}{l}\text { Knowledge } \\
\text { Sharing } \\
\text { Effectiveness }\end{array}$ & $<---$ & $\begin{array}{l}\text { Extrinsic } \\
\text { Motivation }\end{array}$ & .349 & .079 & 4.424 & $* * *$ & Sig \\
\hline $\begin{array}{l}\text { Knowledge } \\
\text { Sharing } \\
\text { Effectiveness }\end{array}$ & $<--$ & Leadership Style & .320 & .106 & 3.018 & .122 & Not Sig \\
\hline $\begin{array}{l}\text { Knowledge } \\
\text { Sharing } \\
\text { Effectiveness }\end{array}$ & $<--$ & $\begin{array}{l}\text { Workplace } \\
\text { Sprituality }\end{array}$ & .501 & .096 & 5.219 & $* * *$ & Sig \\
\hline $\begin{array}{l}\text { Knowledge } \\
\text { Sharing } \\
\text { Effectiveness }\end{array}$ & $<--$ & $\begin{array}{l}\text { Communication } \\
\text { Skill }\end{array}$ & .346 & .125 & 2.768 & .011 & Sig \\
\hline $\begin{array}{l}\text { Knowledge } \\
\text { Sharing } \\
\text { Effectiveness }\end{array}$ & $<---$ & Trust & -.063 & -.174 & 0.364 & .166 & Not Sig \\
\hline
\end{tabular}

Table 5. Model-fit indices for structural models

\begin{tabular}{|l|l|l|}
\hline Model-fit Indices & Results & Recommended Value \\
\hline Chi-square/df & 2.80 & $\leq 3$ \\
\hline GFI & 0.945 & Close to 1 \\
\hline AGFI & 0.937 & Close to 1 \\
\hline NFI & 0.887 & Close to 1 \\
\hline CFI & 0.912 & Close to 1 \\
\hline RMSEA & 0.063 & $\leq 0.07$ \\
\hline
\end{tabular}

Source: Adapted from Hair et al. (1995). 


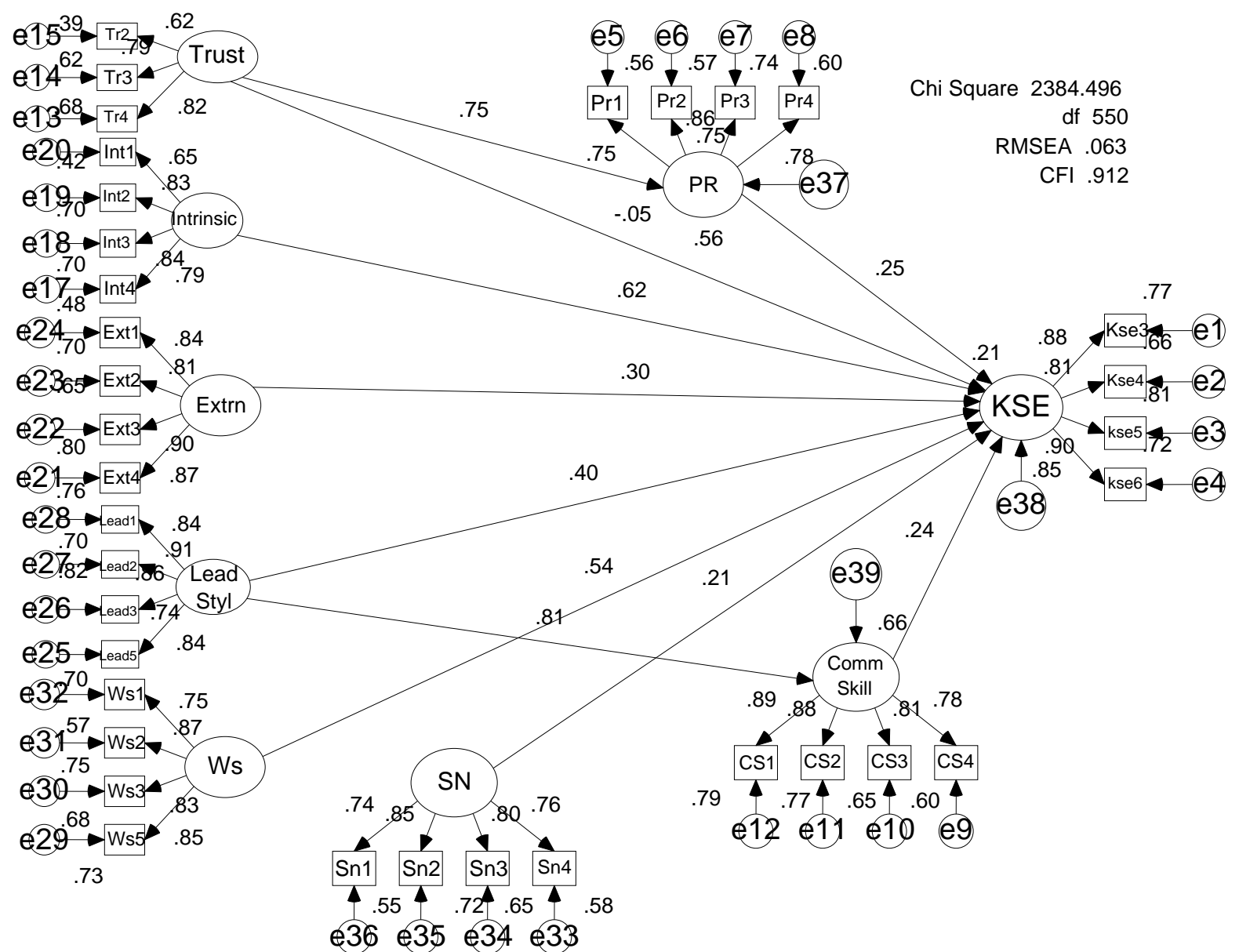

Figure 3. The structural model of knowledge sharing effectiveness among non-academic administrative staff of higher learning institutions

Source: Authors' own processing. (Note $;$ Extrn $=$ Extrinsic Motivation, Lead_Styl $=$ Leadership Style, WS $=$ Workplace Spirituality, SN= Social Network, Comm_Skill = Communication Skill, KSE = Knowledge Sharing Effectiveness)

For testing the mediation impact of perceived risk in between the relationship of trust and knowledge sharing effectiveness this research adopts Baron and Kenny's (1986) research. They proposed that a variable function as a mediator when it achieves the following three criteria:

(1) The exogenous variables significantly influences the mediating variable

(2) The mediating variable significantly influences the dependent variable

(3) When condition one and two are controlled, a previously significant relationship between the exogenous variables and the endogenous variable is no longer significant. Based on the above rules suggested by the scholars, this research revealed that the relationship between trust and perceived risk is a significant relationship $(\beta=.655$, CR $=8.581, \mathrm{P}=0.000)$. In summation to the influence of perceived risk on knowledge sharing effectiveness also significant $(\beta=.243, \mathrm{CR}=2.556, \mathrm{P}=0.016)$.

So, when these two relationships were controlled for, a previously significant relationship between the exogenous variables and the endogenous variable is no

Vol. 10, No. 4, Winter, pp. 284-303, ISSN 1842-0206 | Management \& Marketing. Challenges for the Knowledge Society 
longer significant. As a result, this research explored that the perceived risk plays a strong mediator in between the relationship of trust and knowledge sharing effectiveness among the non-academic staff of higher learning institutions. As a result this research accepted $\mathrm{H} 1$. The direct effect of leadership style on knowledge sharing effectiveness was tested as a first step. Here the path was not significant (see table 4). After introducing the mediator variable (i.e. Communication skill), this relationship became significant, indicating that communication skill has a fully mediating effect in between the relationship between leadership style and non-academic staff knowledge sharing effectiveness (See Table 4). As a result the outcome of this research accepts H2.

\section{Discussion, implications, and future studies}

The findings of this research extensively link with the prior understanding of knowledge sharing effectiveness, especially in a higher learning institutions context under a particular environment; unfolding that all the variables play a significant direct relationship with knowledge sharing effectiveness except leadership style within the scope of non-academic staff of higher learning establishments.

The role of trust play as a significant influence on non-academic staff knowledge sharing effectiveness in higher learning institutions when perceived risk play as a mediating role. Thus, the present research contributes to the knowledge sharing field by offering an inner understanding of trust by considering the perceived risk of staff for the purpose of knowledge sharing effectiveness within their colleagues. As a result the mangers and the policy makers need to minimize the perceived risk in order to enhance the development of trust within the staff of the institutions.

The findings of our study also proved the necessity of extrinsic (i.e. Wage increase, promotion etc.) and intrinsic motivation (i.e. Positive feelings of helping others, enhancing institutional capabilities, and so forth) in expanding the knowledge sharing effectiveness among the non-academic staff of higher learning institutions. So managers need to point out the desire motivational instrument (i.e. Tangible or intangible) of each individual employee for optimizing the knowledge sharing effectiveness.

This study also offers a contribution to knowledge sharing effectiveness by linking the relationship between leadership style and knowledge sharing effectiveness where communication skill applied a crucial mediation variance between these relationships. The researchers considered that by looking into the influence of leadership style as an antecedents of non-academic staff knowledge sharing effectiveness and the mediating role of the communication skill's effect; not only help higher learning institutions to understand how much the staff consider the presence of communication skill require by the leaders to facilitate the cultivation of knowledge sharing among the employees. Thus the mediating effect of communication skill between leadership style and knowledge sharing effectiveness shows that the effectiveness of knowledge sharing can largely influence that variable (i.e. communication skill of the leaders). The role of communication skill among the managers is an essential factor to enhance staff knowledge sharing effectiveness in the Malaysian higher learning institutions. Particularly, the policy makers of higher 
MMCKS learning institutions should pay more attention to the communication skill of the unit managers. By improving the communication skill, managers under a different department of higher learning institutions may foster pleasant conditions that inspire their sub-ordinates to effectively share their knowledge with others.

The outcomes of this research also indicate that workplace spirituality has a significant positive relationship with non-academic staff knowledge sharing effectiveness. Based on this relationship, the researchers argue that when the staff has the higher affective and normative commitment then they will feel a sense of community relationship among their colleagues which may turn a unique environment of knowledge sharing among the staff. Therefore, the management of higher learning institutions needs to create a work-environment where the sense of community among the teams, feeling of respecting others values, feelings of respecting the institutional values, tended to assist others colleagues and experience of enjoyment of the workplace may exist.

Above all, this research also examined the extent of the relationship between online social network and knowledge sharing effectiveness. The result of this research explored that there is a strong relationship between use of online social networking and knowledge sharing effectiveness. Our findings suggest that the majority of the respondents agreed that sites such as LinkedIn and Facebook or the Whatsapp application are valuable components to effectively operate the knowledge sharing culture in the work environment. So this research suggests that managers of higher learning institutions should promote the use of various online communities as practices of their daily jobs.

Due to the constraints of data collection in the sector of higher learning institutions, the future research might be conducted on a comprehensive sample from department wise by adding others antecedents of knowledge sharing effectiveness in order to extend the study in these areas. Future studies should also be undertaken by using different measurements for motivation by looking at the role of Gender as a moderately effective. The above mentioned limitations may influence others researchers to conduct further empirical examination in this area to contribute knowledge sharing research in higher learning institutions. Finally, this research provides an empirical support that shows the combined effects of all the major antecedents of knowledge sharing effectiveness under the perspective of nonacademic staff of higher learning institutions.

\section{Reference}

Adler, P.S. (2002), Market, hierarchy, and trust: The knowledge economy and the future of capitalism. In C. W. Choo and N. Bontis (Eds.), The strategic management of intellectual capital and organizational knowledge, Oxford University Press, New York.

Akhavan, P., Rahimi, A., and Mehralian, G. (2013), "Developing a model for knowledge sharing in research centers", VINE, The Journal of Information and knowledge management system, Vol. 43 No.3, pp. 357-393.

Axley, S. (1996), Communication at work: management and the communication intensive organization. Westport, Conn: Quorum. 
Azman, I., Afiqah, F.N., Madi, A.M. and Huda, M.M.N. (2013), "A Study Of The Correlation Between Training Administration And Training Motivation", Management \& Marketing Challenges for the Knowledge Society, Vol. 8, No. 1, pp. 95-108.

Baron, R.M. and Kenny, D.A. (1986), "The moderator-mediator variable distinction in social psychological research: conceptual, strategic, and statistical considerations", Journal of Personality and Social Psychology, Vol. 51, No. 6, pp. 1173-1182.

Bock, G.W. and Kim, Y.G. (2002), "Breaking the Myths of Rewards: An Exploratory Study of Attitudes about Knowledge Sharing", Information Resource Management Journal Vol. 15, No. 2, pp. 14-21.

Bollinger, A.S. and Smith, R.D. (2001), "Managing organizational knowledge as a strategic asset”, Journal of Knowledge Management, Vol. 5, pp. 8-8.

Bosua, R., and Scheepers, R. (2007), "Towards a model to explain knowledge sharing in complex organizational environments", Knowledge Management Research \& Practice, Vol. 5, No. 2, pp. 93-109.

Bratianu, C. and Orzea, I. (2011), "Organizational knowledge dynamics", Management \& Marketing. Challenges for the Knowledge Society, Vol. 5, No. 3, pp. 41-62.

Bukowitz, W. and Williams, R. (1999), "Looking through the knowledge glass", CIO Enterprise, Section 2, pp. 81-85.

Cohen, S., (1988), The effective public manager: Achieving success in government, San Francisco, Jossey-Bass.

Connelly, C. and Kelloway, E. (2003), “Predictors of employees' perceptions of knowledge sharing cultures", Leadership \& Organization Development Journal, Vol. 24, No. 5, pp. 294-301.

Cook, J., and Wall, T. (1980), "New Work Attitude Measures of Trust, Organizational Commitment and Personal Need Non-Fulfilment", Journal of Occuptational Psychology, Vol. 53, pp. 39-52.

Cross, R., Parker, A., and Borgatti, S.P. (2002), "A bird's-eye view: Using social network analysis to improve knowledge creation and sharing", IBM Institute for Business Value, pp.1669-1700.

Cuieford, J.P. (1965), Fundamental Statistics in Psychology and Education, 4th ed., McGraw-Hill, New York.

Davenport, T.H., and Prusak, L. (1998), Working knowledge, Business Press.

Davenport, T., de Long, D., and Beers, M. (1998), "Successful knowledge management projects", Sloan Management Review, Vol. 39, No.2, pp. 43-57.

de Long, D.W. (1997), Building the Knowledge-Based Organisation: How Culture drives knowledge behaviors. Boston: Center for Business Innovation, Ernst \& Young LLP.

de Long, D.W., and Fahey, L. (2000), "Diagnosing cultural barriers to knowledge management", Academy of Management Executive, Vol. 14, No. 4, pp. 113-127.

Deci, E.L. (1976), Intrinsic Motivation, Plenum Press, London.

Ellahi, A.A. and Mushtaq, R., (2011), Probing Factors Affecting Knowledge Sharing Behavior of Pakistani Bloggers, The Electronic Journal on Information Systems in Developing Countries, Vol. 45, No. 6, pp. 1-14. 
MMCKS Fong, C.Y., Ooi, K.B., Tan, B.I., Lee, V.H. (2011), "HRM Practices and Knowledge 300 Sharing: an Empirical Study", Int. J. Manpower, Vol. 32, No. 54, pp. 704-728.

Goh, S. (2002), "Managing effective knowledge transfer: an integrative framework and some practice implications", Journal of Knowledge Management, Vol. 6, No. 1, pp. 23-30.

Gold, A.H., Malhotra, A., and Segars, A.H. (2001), "Knowledge management: An organizational capabilities perspective", Journal of Management Information Systems, Vol. 18, No. 1, pp. 185-214.

Gruenfeld, D.H., Mannix, E.A., Williams, K.Y. and Neale, M.A. (1996), “Group composition and decision making: how member familiarity and information distribution affect process and performance", Organizational Behavior and Human Decision Process, Vol. 67, No. 1, pp. 1-15

Hair, J.F., Jr., Anderson, R.E., Tatham, R.L. and Black, W.C. (1995) Multivariate Data Analysis, 3rd ed, Macmillan Publishing Company, New York.

Hinds, P.J., and Pfeffer, J. (2003), Why organizations don't "know what they know": Cognitive and motivational factors affecting the transfer of expertise. In $\mathrm{M}$. Ackerman, V. Pipek \& V. Wulf (Eds.), Beyond knowledge management: Sharing expertise (pp. 3-26). Cambridge, MA: MIT Press.

Hislop, D. (2003), "Linking human resource management and knowledge management via commitment: A review and research agenda", Employee Relations, Vol. 25, No. $1 / 2$, pp. 182-202.

Hoch, J.E., and Kozlowski, S.W.J. (2013), "Leading virtual teams: Hierarchical leadership, structural supports, and shared team leadership", Journal of Applied Psychology, Vol. 99, No. 3, pp. 390-403.

Hofstede, G.H. (1991), Culture and organizations - Software of the mind. London: Harper Collins.

Howard, S. (2002), "A spiritual perspective on learning in the workplace”, Journal of Managerial Psychology, Vol. 17, No. 3, pp. 230-242.

Janz, B.D., and Prasarnphanich, P. (2003), "Understanding the antecedents of effective knowledge management: The importance of a knowledge-centered culture", Decision Sciences, Vol. 34, No. 2, pp. 351-384.

Jurkiewicz, C.L., and Giacalone, R.A. (2004), "A Values Framework for Measuring the Impact of Workplace Spirituality on Organizational Performance", Journal of Business Ethics, Vol. 49, No. 2, pp.129-142.

Kinjerski, V.M., and Skrypnek, B.J. (2004), "Defining spirit at work: finding common ground”, Journal of Organizational Change Management, Vol. 17, No. 1, pp. 2642.

Kotter, J.P., and Heskett, J.L. (1992), Corporate culture and performance, New York: The Free Press.

Kreps, D.M. (1997), "Intrinsic motivation and extrinsic incentives", The American Economic Review, Vol. 87, No. 2, pp. 359-64.

Kuo, T.H. (2013), "How expected benefit and trust influence knowledge sharing", Industrial Management \& Data Systems, Vol. 113, No. 4, pp. 506-522.

Lilleoere A.M., and Hansen E.H. (2011), "Knowledge-Sharing enablers and Barriers in Pharmaceutical Research and Development", J. Knowl. Manage. Vol. 15, No. 1, pp. 53-70. 
Lin, C.-P. (2007), "To share or not to share: Modeling tacit knowledge sharing, its mediators and antecedents", Journal of Business Ethics, Vol. 70, pp. 411-428.

Lindenberg, S. (2001), "Intrinsic motivation in a new light”, Kyklos, Vol. 54, pp. 317-42.

Long, B.S., and Mills, J. H. (2010), “Workplace spirituality, contested meaning, and the culture of organization: A critical sense making account", Journal of Organizational Change Management, Vol. 23, No. 3, pp. 325-341.

Mayer, R.C., Davies, J.H., and Schoorman, F.D. (1995), "An Integrative Model of Organizational Trust”, Academy of Management Review, Vol. 20, No. 3, pp.709734.

McCarthy, J.F., Congleton, B., Maxwell Harper, F. (2008), The Context, Content and Community Collage: Sharing Personal Digital Media in the Physical Workplace. Conference paper CSCW'08 (Computer Supported Cooperative Work), November 8-12, 2008.

McDermott, R., and O'Dell, C. (2001), "Overcoming cultural barriers to sharing knowledge", The Journal of Knowledge Management, Vol. 5, No. 1, pp. 76-85.

McEvily, B., Perrone, V., and Zaheer, A. (2003), "Trust as an Organizing Principle", Organization Science, Vol. 14, No. 1, pp. 91-103.

Meek, V.L. (1988), “Organizational Culture - Origins and Weaknesses”, Organization Studies, Vol. 9, No. 4, pp. 453-473.

Milliman, J., Czaplewski, A.J., and Ferguson, J. (2003), "Workplace spirituality and employee work attitudes: An exploratory empirical assessment" Journal of Organizational Change Management, Vol. 16, No. 4, pp. 426-447.

Mitchell, R.J., and Boyle, B. (2009), "A theoretical model of transformational leadership's role in diverse teams", Leadership \& Organization Development Journal, Vol. 30, No. 5, pp. 455-474.

Newell, S., Robertson, M., Scarbrough, H., and Swan, J. (2002), Managing Knowledge Work, Basingstoke u.a.: Palgrave.

Nonaka, I. and N. Konno (1998), “The concept of 'Ba':building a foundation for knowledge creation", California Management Review, Vol. 40, No. 3, pp. 40-54.

Nunnally, J.C. (1978), Psychometric Theory, 2nd ed., McGraw-Hill, New York.

Osterloh, M. and Frey, B. (2000), "Motivation, knowledge transfer, and organisational forms", Organisation Science, Vol. 11 No. 5, pp. 538-50.

Osterloh, M., and Frey, B.S. (2000), "Motivation, knowledge transfer, and organizational forms", Organization science, pp. 538-550.

Panahi, S., Watson, J., and Partridge, H. (2012), "Social Media and Tacit Knowledge Sharing: Developing a Conceptual Model," in: World Academy of Science, Engineering and Technology (WASET). Paris, France: pp. 1095-1102.

Pieterse, A.N., van Knippenberg, D., Schippers, M., and Stam, D. (2010), "Transformational and transactional leadership and innovative behavior: The moderating role of psychological empowerment", Journal of Organizational Behavior, Vol. 31, No. 4, pp. 609-623.

Politis, J. (2003), "The connection between trust and knowledge management: what are its implications for team performance", Journal of Knowledge Management, Vol. 7, No. 5, pp. 55-66.

Rousseau, D.M. (1995), Psychological contracts in organizations: understanding written and unwritten agreements. Thousand Oaks: Sage. 
MMCKS Shin, S.J., and Zhou, J. (2003), "Transformational leadership, conservation, and creativity: Evidence from Korea", Academy of Management Journal, Vol. 46, No. 6, pp. 703-714.

Smith, A. and Rupp, W. (2002), "Communication and loyalty among knowledge workers: a resource of the firm theory view", Journal of Knowledge Management, Vol. 6, No. 3, pp. 250-61.

Smith, J. (2003), "Building an entrepreneurial knowledge culture in a national research laboratory". $R$ \& D Management, Vol. 33, No. 2, pp. 231-237.

Snyder, J. and Lee-Partridge, J.E. , (2013), "Understanding communication channel choices in team knowledge sharing", Corporate Communications: An International Journal, Vol. 18, Vol. 4, pp. 417-431.

Suri Babu, G., Gupta, K.S., and Ahmed, S. (2007a), Leadership styles and knowledge sharing: a conceptual relationship, Paper presented in the International Conference on Emerging Competitiveness Paradigm, Goa, India, 9-12 January 2007, organised by Indiana University of Pennysilva, USA.

Suri Babu, G., Gupta, K.S., and Ahmed, S. (2007b), Knowledge management and leadership styles: a conceptual relationship. Paper presented in the8th International Research Conference on Quality, Innovation and Knowledge Management, New Delhi, India, 10-13, February 2007. Organized by Monash University, Australia.

Suri Babu, G., Gupta, K.S., and Ahmed, S. (2007c), Leadership capability and knowledge management success: framework. Paper presented at the UGC Sponsored National Seminar on High Performance Organisations and Knowledge Management, SIBER, Kolhapur, 5-7, March 2007.

Suri Babu, G., Ghosh, S.N., Gupta, K.S., and Ahmed, S. (2007e), Knowledge management: a study measurement approach. Paper accepted forSecond International Conference on Management IBSA.ICON'07,Ahmedabad, 27-29, December.

Suri Babu, G., Mohana Rao, T., Yogendra, D.R., Gupta, K.S., and Ahmed, S. (2007d), Leadership capability: a study measurement approach. Paper presented at National Conference on Changing Paradigms in Management, Annamalai University, Annamalai Nagar, September 2007.

Syed-Ikhsan, S. and Rowland, F. (2004), "Knowledge management in public organizations: a study on the relationship between organizational elements and the performance of knowledge transfer", Journal of Knowledge Management, Vol. 8, No. 2, pp. 95-111.

Szulanski, G., Cappetta, R., and Jensen, R.J. (2004), "When and How Trustworthiness Matters: Knowledge Transfer and teh Moderating Effect of Causal Ambiguity", Organization Science, Vol. 15, No. 5, pp. 600-613.

Tsai, W. (2001), "Knowledge transfer in intra-organizational networks: Effects of network position and absorptive capacity on business unit innovation and performance", The Academy of Management Journal, Vol. 44, No. 5, pp. 9961004.

Tse, H.H.M., and Mitchell, R.J. (2010), A theoretical model of transformational leadership and knowledge creation: The role of open-mindedness norms and leader-member exchange, Journal of Management \& Organization, Vol. 16, No. 1, pp. 83-99. 
Van Muijen, J.J. (1994), Organisatiecultuur en organisatieklimaat, de ontwikkeling van een meetinstrument op basis van het competing values model. (Doctoral dissertation, Free University of Amsterdam, 1994). Retrieved from http://dspace.ubvu.vu.nl/bitstream/1871/15432/1/251.pdf

VanDenHooff, B., and VanWeenen, F.d.L. (2004), Committed to share: Commitment and $\mathrm{CMC}$ use as antecedents of knowledge sharing. Knowledge and Process Management, Vol. 11, No. 1, pp. 13-24.

Vasconcelos, A.F. (2013), “Examining Workers' Perceptions Of Spirituality In The Workplace: An Exploratory Study", Management \& Marketing Challenges for the Knowledge Society, Vol. 8, No. 2, pp. 231-260.

Viadesk B.V. (2011), Social Media op de werkvloer: Professional initiatiefrijk, werkgever behoudend. Onderzoek naar slimmer samenwerken met Social Media. Amsterdam.

Wellman, B., Salaff, J., Dimitrova, D., Garton, L., Gulia, M., and Haythornthwaite, C. (1996), Computer networks as social networks: Collaborative work, telework, and virtual community. Annual Review of Sociology, Vol. 22, pp. 213-238.

Yaghi, K., Barakat, S., Alfawaer, Z. M., Shkokani, M. ,Nassuora, A. (2011), "Knowledge Sharing Degree among the Undergraduate Students: A Case Study at Applied Science Private University", International Journal of Academic Research, Vol. 3. No. 1.

Zabriskie, M.S. (2005), College student definitions of religiosity and spirituality. (Unpublished doctoral dissertation). University of Michigan, Ann Arbor, MI.

Zohar, D., and Marshall, I. (2004), Spiritual Capital: Wealth We Can Live By, SA: Berret-Koehler Publishers, Inc. 